\title{
ДИНАМИКА КАРСТОВЫХ ПРОВАЛОВ НА ТЕРРИТОРИИ РАЙОНОВ ПРЕИМУЩЕСТВЕННО СУЛЬФАТНОГО КАРСТА ПЕРМСКОГО КРАЯ
}

\author{
О.И. Кадебская, М.В. Богомаз \\ Горный институт УрО РАН, г. Пермь
}

\begin{abstract}
Аннотация: Статья содержит информацию о количестве карстовых провалов в пределах районов преимущественно сульфатного карста Пермского края за последние 100 лет.

Ключевые слова: сульфатный карст, безопасность жизнедеятельности, Пермский край.

\section{Введение}

В области распространения сульфатных отложений на территории Пермского края наиболее часто встречающимися формами опасных поверхностных проявлений карстовых процессов являются провалы. Согласно К.А. Горбуновой и др. (1992 г.) на территории Пермского края выделяются 11 районов, где присутствуют сульфатные отложения. Кунгурская лаборатория-стационар ГИ УрО РАН регистрировала провалы в пределах наиболее заселенных территорий 5 районов: Полазненском, Иренском, Кишертско-Суксунском, Нижнесылвинском и Косьвинско-Лысьвенском (рис. 1).
\end{abstract}

Полазненский карстовый район. Район занимает центральную часть Пермского края, его площадь составляет 2383,47 км². С запада он захватывает часть правого берега Камского водохранилища, с юга ограничен долиной реки Чусовой, с севера и востока - бассейнами Добрянки, Вильвы и Усолки. Северо-западная граница проходит по контакту закарстованных соликамских пород с шешминскими, северная и восточная имеют сложные очертания и определяются литологией пород (Горбунова, 1992). Наиболее закарстованы гипсы и ангидриты иренской свиты кунгурского яруса.

На территории района выделено 12 карстовых участков. На участках встречаются карры, карстовые рвы, котловины, овраги, сухие речки и озера. Выявлены карстовые депрессии, заполненные брекчией. Наибольшая закарстованность (до 1056-1072 воронок на $1 \mathrm{\kappa м}^{2}$ ) приурочена к прибортовым участкам водохранилища у д. Бесово, Константиновка и северозападнее д. Мохово. Средняя плотность карстовых форм на участке составляет 60 шт/км². Большинство провалов выявлено на Полазненском карстовом участке, расположенном на левобережье Камского водохранилища в окрестностях пгт. Полазна, и Шалашнинском карстовом участке, занимающим правобережную часть Чусовского залива Камского водохранилища. Согласно наблюдениям в районе зафиксировано 79 провалов. Средние размеры провалов составляют до 3 м в поперечнике и до 5 м глубиной (7 провалов с максимальными размерами 10 м в поперечнике и глубиной 6-10 м; самый крупный произошел в 1951 г. в 2 км к юго-востоку от д. Ивановка, его размеры составляли 25 х 20 м и глубину 15 м).

\section{Иренский карстовый район}

Является классическим примером сульфатного карста, занимает правобережную часть бассейна р. Ирени, его площадь составляет 3399,70 км². С востока он ограничен карбонатными породами филипповского горизонта кунгурского яруса. В административном отношении расположен на территории Ординского, Уинского и Октябрьского районов Пермского края. Западная граница проводится по левобережью р. Ирени, где иренский горизонт погружается на запад и перекрывается соликамским, а затем терригенным шешминским горизонтом. На севере за границу с Нижнесылвинским карстовым районом условно принимается широтный отрезок р. Ирени (Горбунова и др., 1992). Наиболее закарстованы гипсы и ангидриты иренской свиты кунгурского яруса. 


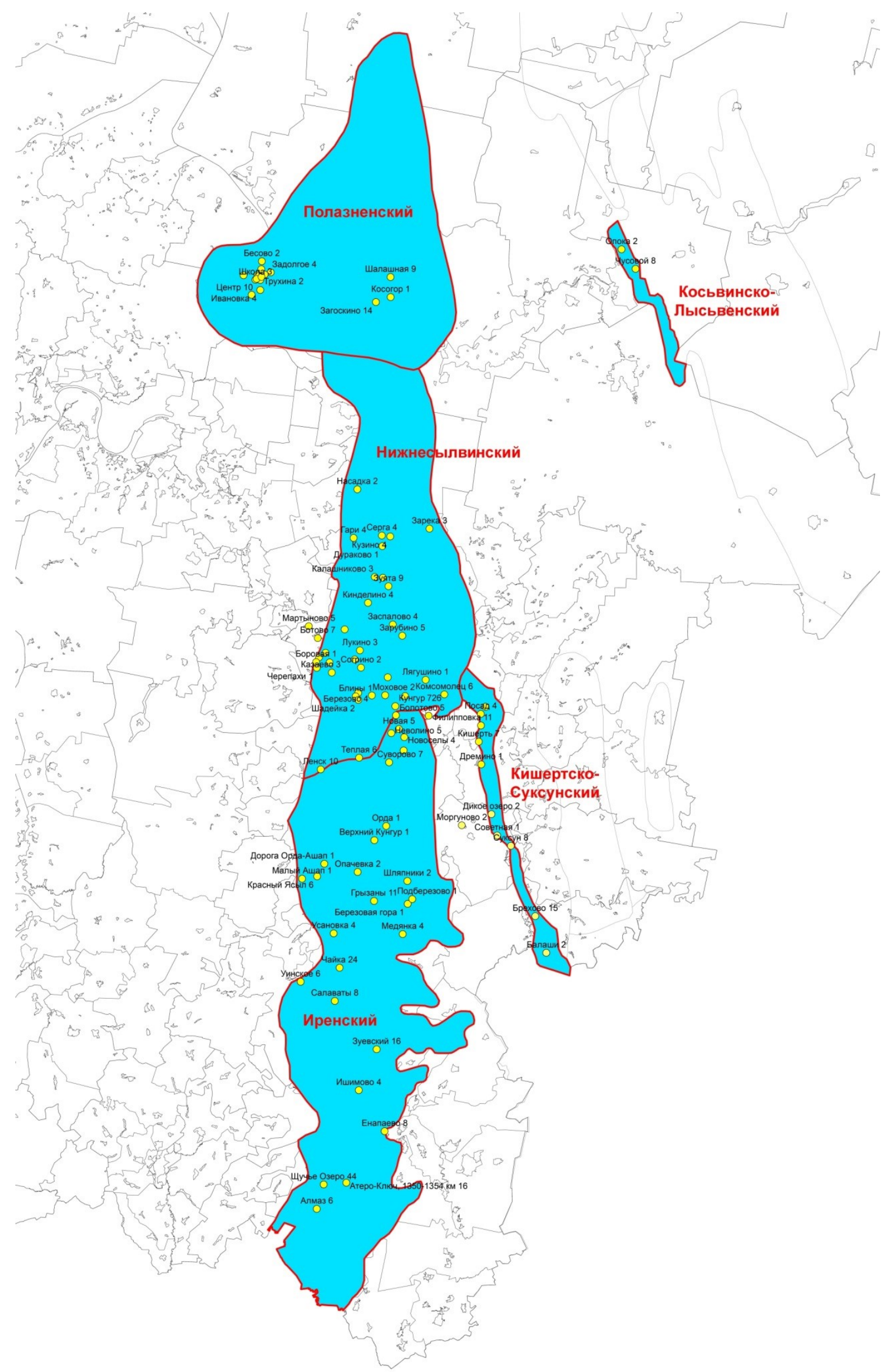

Рис. 1. Площадное распространение провалов за последние 100 лет на территории районов сульфатного карста Пермского края 
Район расположен на восточной окраине Восточно-Европейской платформы. Он находится на границе двух крупных структур: Башкирского свода и БымскоКунгурской впадины, осложненных мелкими и средними структурами. Одна из них Уфимский вал (макробрахиантиклиналь). Иренский карстовый район занимает западное, более пологое по сравнению с восточным, крыло вала (Горбунова и др., 1992). Карст на данной территории отличается большим количеством провалов, внушительной плотностью карстовых форм, крупными коэффициентами поверхностной и глубинной закарстованности. Согласно наблюдениям Горного института, за последние 100 лет в данном районе зафиксировано 197 провалов. В с. Шляпники с 1956 г. по 1978 г. зафиксировано 6 провалов, из них самый крупный - в 1972 г., диаметр 30 м, - сопровождался легким землетрясением.

В с. Красный Ясыл с 1959 по 1979 г.г. произошло 7 карстовых провалов, в том числе в 1977 г. у колхозного общежития площадью 10 х 12 м и глубиной 8 м, в 1979 г. провал возник в зернохранилище. В 1949 г. на юго-западной окраине села Опачевка провалился и утонул во вскрывшемся подземном водоеме Е. Игошев. Еще раньше, как вспоминали старожилы, в похожий провал упала корова, но не утонула. Неподалеку от села в 60 -е годы на поле между Климихой и Губанами во время ночной вспашки вместе с землей провалился гусеничный трактор И.В. Трясцына. В 1905 г. в д. Озерки обвалился крестьянский дом со всеми постройками.

\section{Нижснесыльинский карстовый район}

Нижнесылвинский район находится на территории северо-восточной части Кунгурского и небольшой западной части Березовского районов, расположен в бассейне нижнего течения р. Сылвы.

Район занимает восточную окраину Восточно-Европейской платформы на границе с Предуральским прогибом и приурочен к Бымско-Кунгурской впадине. Площадь Нижнесылвинского района составляет 2183,84 км². Крупные структуры осложнены Мазунинской и Веслянской валообразными зонами, в пределах которых выделяются локальные структуры меньших размеров (Горбунова, 1992).

В строении осадочного чехла района принимают участие породы кунгурского яруса приуральского отдела пермской системы и породы неогеновой и четвертичной систем. Карст проявляет себя преимущественно в гипсах и ангидритах. Данная территория, особенно ее южная часть, отличается существенной техногенной нагрузкой. Множество провалов зафиксировано на застроенных участках, автомобильных дорогах и железнодорожных путях. За последние 100 лет в данном районе обнаружено 128 провалов. Обычные размеры провалов составляют до 3 м в поперечнике и до 4 м глубиной. Девять провалов с максимальными размерами 8-14 м в поперечнике и глубиной 5-18 м; 2 самых крупных провала произошли в 1975 г. в районе д. Зарубино рядом с дорогой в д. Каширино с размерами 25 м в диаметре и 2 м глубиной и в 2019 г. в д. Лукино с размерами $18 \times 16$ м и глубиной 10 м.

Провалы на территории г. Кунгура в рамках района не учитывались, так как их несоизмеримо больше за счет количества провалов, связанных с утечками из водонесущих коммуникаций. Всего на территории города за последние 100 лет зафиксировано 718 провалов. Среднестатистический размер провалов - 3 м в диаметре и 3 м в глубину. Самый крупный по диаметру провал произошел в 1973 г., его первоначальные размеры составляли 20 на 15 м. Самый глубокий провал на территории города произошел возле ИТК № 40 в 2001 г, его глубина составила $20 \mathrm{M}$. 


\section{Кишертско-Суксунский карстовый район}

Район проходит узкой полосой вдоль восточного склона северного окончания Уфимского плато. На данной территории доминируют закрытый и подаллювиальный типы карста.

Карстовые и эрозионно-карстовые депрессии являются более зрелыми формами сульфатного карста данного района, они имеют поперечник более 1 км и вытянуты вдоль восточного крыла Уфимского вала. Наиболее крупными из них являются Низковская, Дреминская, Бурцевская, Мазуевская, Суксунско-Советинская и Дикоозерская.

Несмотря на маленькую площадь $\left(\approx 356\right.$ км² $^{2}$, в данном районе зафиксировано 49 провалов с размерами до 7 м в поперечнике и до 4 м глубиной (5 провалов с максимальными размерами до 12-20 м в поперечнике и до 17 м глубиной). Самый крупный в с. Усть-Кишерть на II террасе р. Сылвы - 28-29 августа 1949 г. образовалось три провала. Вначале на поверхности земли появилось блюдцеобразное понижение, в северозападной стенке которого возникла трещина. Затем началось обрушение, сопровождавшееся шумом и излиянием воды. Спустя пять часов обрушение возобновилось. К первому провалу присоединился второй. Они заполнились водой. Два озера оказались в общей котловине и разделялись гребнем высотой до 1,9 м. Длина котловины была 50,5 м, ширина большей части - 40 м, меньшей - 22 м (Горбунова, 1965). Наибольший по глубине провал произошел в д. Брехово в 1953 г., на момент обследования первоначальная глабина провала составляла 40 м.

\section{Косьвинско-Лысьвенский район}

\section{локального распространения гипсового карста}

Район расположен вдоль восточной границы Предуральского прогиба и ЗападноУральской зоны складчатости. Здесь наиболее закарстованы гипсы лекской и поповской свиты. В разрезе гипсы вскрываются на локальных участках. Наиболее крупные из них - Опокинский, Селищенский, Утесовский, район железнодорожного вокзала в г. Чусовой, Любимовский и Лысьвенский. С 1950 г. на данной территории зафиксировано 10 провалов с обычными размерами до 3 м в поперечнике и до 2 м глубиной (6 провалов с максимальными размерами 5-6 м в поперечнике и глубиной до 3 м; самый крупный провал произошел в 1965 г. в г. Чусовой с размерами 7 на 8 м и глубиной 9 м).

Количество провалов по районам представлено в таблице 1. В Кишертско-

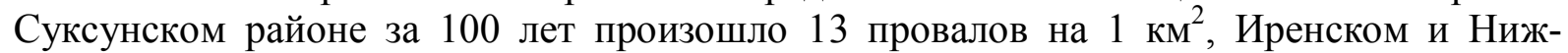
несылвинском районах -5 , в Косьвинско-Лысьвенском - 8, в Полазненском - 3 .

Таблица 1

\begin{tabular}{|c|c|c|c|}
\hline Карстовый район & $\begin{array}{c}\text { Площадь района, } \\
\text { км }^{2} \\
\end{array}$ & $\begin{array}{c}\text { Кол-во провалов } \\
\text { за } 100 \text { лет } \\
\end{array}$ & $\begin{array}{c}\text { Кол-во провалов } \\
\text { на } 1 \text { км }^{2} \\
\end{array}$ \\
\hline Полазненский & 2383,47 & 79 & 3,33 \\
\hline Иренский & 3399,70 & 197 & 5,83 \\
\hline Нижнесылвинский & 2183,84 & 128 & 5,88 \\
\hline $\begin{array}{l}\text { Кишертско- } \\
\text { Суксунский }\end{array}$ & 356 & 49 & 13,8 \\
\hline $\begin{array}{l}\text { Косьвинско- } \\
\text { Лысьвенский }\end{array}$ & 115,4 & 10 & 8,6 \\
\hline \multicolumn{2}{|l|}{ Итого: } & 463 & \\
\hline
\end{tabular}


Наибольшее количество провалов зафиксировано в период 1960-1980 гг. (рис. 2). Вероятно, увеличение количества провалов в Полазненском и Нижнесылвинском районах в этот период было связано с подъемом уровня поверхностных и подземных вод после строительства Камской ГЭС в 1954 г, а в Иренском и Кишертско-Суксунском районах с площадной распашкой сельскохозяйственных земель.

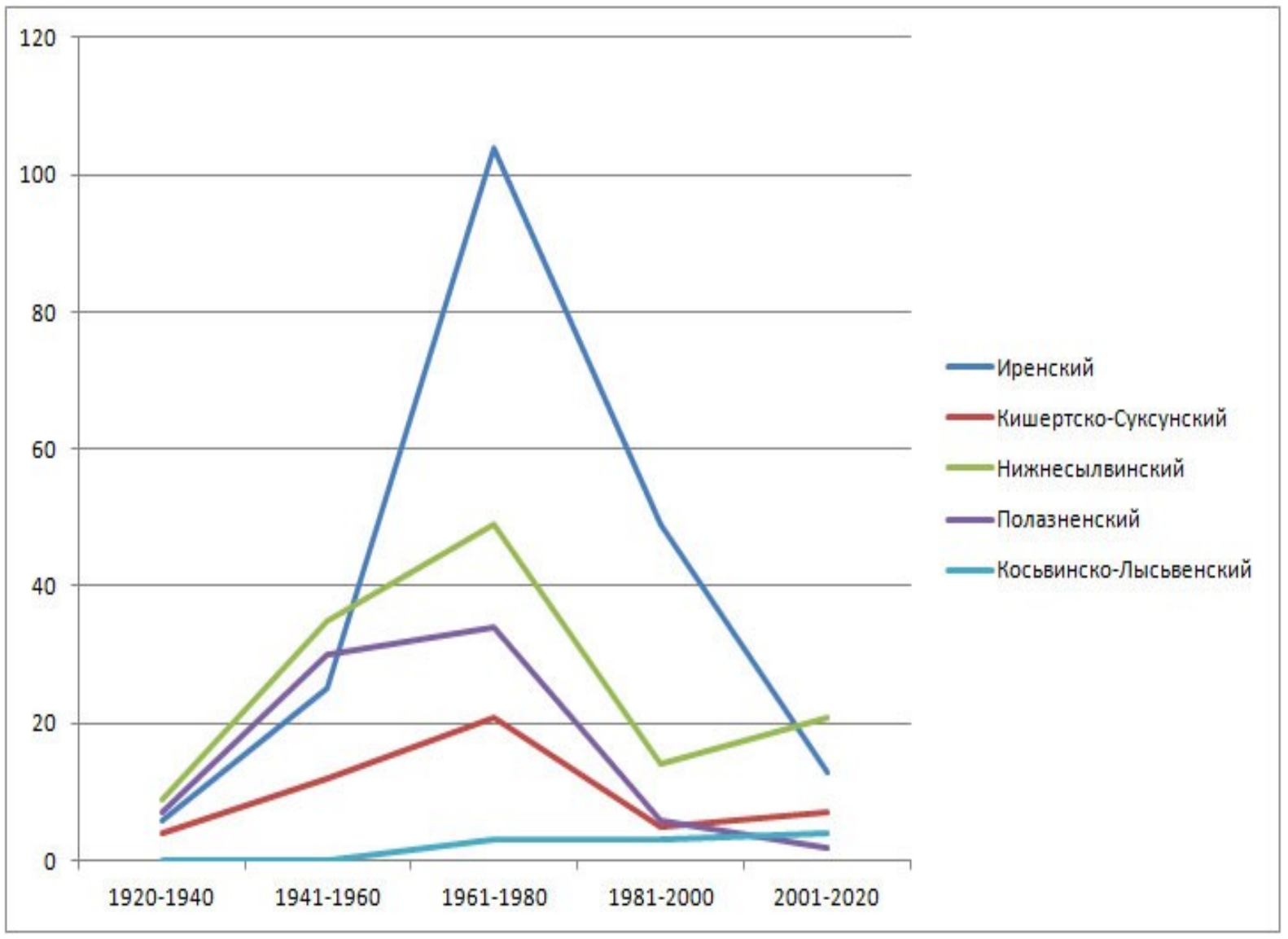

Рис. 2. Динамика количества провалов на территории районов сульфатного карста Пермского края

\section{Выводы}

Карстовые провалы - наиболее динамично развивающиеся формы поверхностного проявления процесса. Их потенциальная катастрофичность в основном определяет понятие карстоопасности. Образование подобных провалов представляет реальную опасность для жизнедеятельности на территории городов и угрожает эксплуатационной сохранности инженерных объектов. Оценка карстоопасности освоенных территорий должна основываться на данных мониторинговых наблюдений за провальными явлениями. Карстоопасность определяется не только интенсивностью образования, но и их размерами - в первую очередь диаметром. Общая площадь районов распространения сульфатного карста, где зафиксировано наибольшее количество провалов, более $8000 \mathrm{~km}^{2}$. Данные мониторинговых наблюдений в пределах населенных пунктов позволили выделить участки 1 категории опасности. Прежде всего это участки с высокоэтажной застройкой в г. Кунгур, п. Полазна, п. Усть-Кишерть, г. Чусовой, Хохловский участок Орджоникидзевского района г. Перми, а также территории с. Березовая гора, д. Балаши, д. Брехово, д. Дикое озеро, д. Советянка, с. Шляпники, с. Тюйное, Двуреченского, Дивь- 
инского, Зарубинского, Комсомольского, Краснослудского, Кыласовского, Красноясыльского, Моховского, Насадского, Сергинского, Судинского, Сылвенского, Щучье-Озерского сельских поселений. Площадь выявленных участков 1 категории

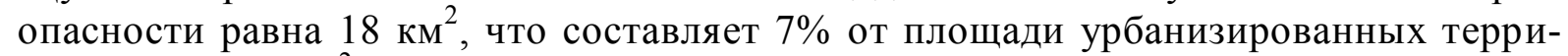

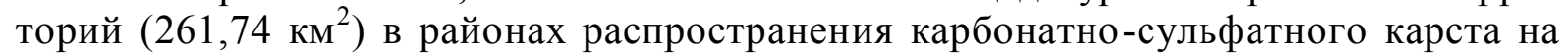
территории Пермского края.

\title{
Исследование выполнено в рамках Государственного контракта № 01562000025190000150001 .
}

\section{БИБЛИОГРАФИЧЕСКИЙ СПИСОК}

1. Горбунова К.А., Андрейчук В.Н., Костарев В.П., Максимович Н.Г. Карст и пещеры Пермской области. - Пермь: Изд-во ПГУ, 1992. - 200 с.: ил.

2. Горбунова К. А. Особенности гипсового карста: Путеводитель по Кишертско-Суксунскому карстовому району. - Пермь: кн. изд-во, 1965. - 120 с.: ил.

УДК 552.53:552.12

DOI:10.7242/echo.2020.4.4

\section{К ВЕЩЕСТВЕННОЙ ХАРАКТЕРИСТИКЕ СИЛЬВИНИТОВ ПЛАСТА КрIV ВЕРХНЕКАМСКОГО МЕСТОРОЖДЕНИЯ СОЛЕЙ (ПЕРМСКИЙ КРАЙ)}

\author{
О.В. Коротченкова \\ Горнылй институт УрО РАН, г. Пермь
}

\begin{abstract}
Аннотация: На сегодняшний день данные по вещественному составу сильвинитового пласта КрIV, не входящего в разрез продуктивной толщи Верхнекамского месторождения калийных солей, практически отсутствуют. Однако именно петрография и геохимия могут внести ясность в вопрос генезиса этого пласта. Приведенные результаты главным образом петрографических исследований указывают на первично-седиментационную природу пород.
\end{abstract}

Ключевые слова: Верхнекамское месторождение, сильвинит, красный IV.

\section{Введение}

Разрез Верхнекамского месторождения калийно-магниевых солей представлен чередованием снизу вверх каменной соли, сильвинитов и карналлитовой породы. Сильвинитовая зона (С3) состоит из пластов сильвинита (снизу вверх): KpIII, KpII, KpI и А с подчиненным количеством пластов каменной соли. Однако при разведочных работах 1960-1970-х годов в юго-западной части месторождения был вскрыт пласт сильвинита (KpIV) в подстилающей каменной соли (ПдКС), то есть ниже подошвы С3. Ряд исследователей [1] считают, что породы являются первично-седиментационными и сформировались локально в самой глубокой части эвапоритового бассейна еще до начала садки основного объема калийных солей, другие [2] предполагают, что они являются фрагментом когда-то существовавшего первого сильвинитового пласта, практически полностью выщелоченного. Третьи [3] связывают их появление в ПдКС с формированием зоны Усольского надвига (тектоническое происхождение).

В публикациях предшественников $[1,2]$ приведены следующие обобщенные данные по характеристикам вскрытого пласта: мощность варьирует в среднем от 0,6 до 1,0 м, в единичном случае 3,45 м, а среднее содержание $\mathrm{KCl}$ - от 5,28 до 23,15\%, нерастворимого в воде остатка $-0,80-2,31 \%$. 